\title{
Magnesium/fish bone derived hydroxyapatite composites by friction stir processing: studies on mechanical behaviour and corrosion resistance
}

\author{
B VANDANA $^{1}$, P SYAMALA ${ }^{1}$, D SRI VENUGOPAL ${ }^{1}$, S R K IMRAN SK ${ }^{1}$, B VENKATESWARLU ${ }^{2}$, \\ M JAGANNATHAM ${ }^{3}$, MAREK KOLENČÍK ${ }^{4}$, I RAMAKANTH ${ }^{5}$, RAVIKUMAR DUMPALA ${ }^{6}$ \\ and B RATNA SUNIL ${ }^{1,7, * \mathbb{D}}$ \\ ${ }^{1}$ Department of Mechanical Engineering, Rajiv Gandhi University of Knowledge Technologies (AP-IIIT), Nuzvid 521202, \\ India \\ ${ }^{2}$ Department of Metallurgical and Materials Engineering, Rajiv Gandhi University of Knowledge Technologies (AP-IIIT), \\ Nuzvid 521202, India \\ ${ }^{3}$ Department of Metallurgical and Materials Engineering, Indian Institute of Technology Madras, Chennai 600036, India \\ ${ }^{4}$ Department of Soil Science and Geology, Faculty of Agrobiology and Food Resources, Slovak University of Agriculture \\ in Nitra, Trieda A. Hlinku 2, 94976 Nitra, Slovak Republic \\ ${ }^{5}$ Department of Chemistry, Rajiv Gandhi University of Knowledge Technologies (AP-IIIT), Nuzvid 521202, India \\ ${ }^{6}$ Department of Mechanical Engineering, Visvesvaraya National Institute of Technology, Nagpur 440010, India \\ ${ }^{7}$ Department of Mechanical Engineering, Bapatla Engineering College, Bapatla 522101, India \\ *Author for correspondence (bratnasunil@gmail.com)
}

MS received 12 June 2018; accepted 7 November 2018; published online 24 April 2019

\begin{abstract}
Magnesium (Mg)-based biomaterials are widely investigated for degradable implant applications. Developing $\mathrm{Mg}$-based composites is one of the strategies adopted to increase the bioactivity and to reduce the degradation rate of $\mathrm{Mg}$. In the present study, hydroxyapatite (fHA) has been produced from fish bones and incorporated into pure Mg sheets by friction stir processing (FSP). Microstructures of the composites clearly revealed the grain refinement in the stir zone up to $10 \mu \mathrm{m}$ from the starting size of $2000 \mu \mathrm{m}$. Measurements of microhardness also indicated the effect of a smaller grain size and the presence of fHA on increasing the hardness in composites. Interestingly from the tensile tests, mechanical properties, such as yield strength and ultimate tensile strengths were measured as they decreased for the composite due to the presence of fHA particles. However, the observed \% elongation of the composite was similar to that of a natural bone. From the electrochemical tests, the composite exhibited an enhanced corrosion performance. From the results, it can be concluded that the cost-effective Mg-fHA composites can be developed by FSP for degradable scaffold applications in biomedical fields.
\end{abstract}

Keywords. Composites; magnesium; fish bone; naturally derived hydroxyapatite; corrosion; FSP.

\section{Introduction}

Magnesium (Mg)-based materials are becoming a promising option for researchers to develop degradable implants for temporary applications in biomedical engineering. $\mathrm{Mg}$ degrades safely in the physiological environment. Additionally, mechanical behaviour of $\mathrm{Mg}$ being close to human bone, brings advantage to reduce the stress shielding effect [1,2]. By using Mg-based implants, necessity of second surgery can be eliminated using $\mathrm{Mg}$ for temporary applications. However, a rapid degree of corrosion is the limitation with $\mathrm{Mg}$-based implants $[3,4]$. There are several methods, such as developing alloys, composites, surface coatings and microstructural modifications which address the corrosion issues in developing Mg-based biomaterials [4-13]. On the other hand, hydroxyapatite (HA), a known bioceramic material, is being widely utilized in the medical industry. Basically, HA is a mineral phase of calcium and phosphorous present in the human bone. HA is produced by several routes which can be grouped into two categories: (i) by using chemical precursors [14-20] or (ii) by deriving from natural resources [21-25]. The addition of HA to biocompatible metals in developing novel composites for implant applications is a good strategy.

Several methods, such as powder metallurgy, melting, extrusion, sintering and friction stir processing (FSP) were adopted in developing $\mathrm{Mg}-\mathrm{HA}$ composites for biomaterial applications [13]. Khanra et al [26] produced Mg-HA composites and reported decreased tensile strength (from 187.9 to $136.7 \mathrm{MPa}$ ) and increased compressive strength (from 265 to $305 \mathrm{MPa}$ ) when HA content was increased from 0 to 15 wt.\%. A similar decrease in tensile strength (from 197.1 to $92.1 \mathrm{MPa}$ ) was also reported by $\mathrm{Gu}$ et al [27], for $\mathrm{Mg}-\mathrm{HA}$ 
composites by adding $30 \mathrm{wt}$ \% HA to $\mathrm{Mg}$ through a powder metallurgy route. Khalil and Amajid [28] used high frequency induction heat sintering to produce $\mathrm{Mg}-1 \% \mathrm{HA}$ composites and observed increase in microhardness (from 50 to $60 \mathrm{Hv}$ ), density (97 to $99 \%$ of theoretical) and compressive strength (150 to $192.7 \mathrm{MPa}$ ) on increasing the sintering time from 1 to 3 min. Interestingly, Viswanathan et al [29] reported decreased corrosion resistance as observed from increased corrosion current densities $\left(i_{\text {corr }}\right)$ from 0.778 to $0.873 \mathrm{~mA} \mathrm{~cm}^{-2}$ for the Mg-20\% HA composite produced by powder metallurgy. However, after plasma electrolytic oxidation (PEO) treatment, the $i_{\text {corr }}$ value was observed as decreased to 0.00062 for the $\mathrm{Mg}-20 \% \mathrm{HA}$ composite, which is an indication for increased corrosion resistance. In our earlier study, $\mathrm{Mg}-\mathrm{HA}$ composites were produced by FSP and a fine-grained composite (grain size of $2 \mu \mathrm{m}$ ) was developed that exhibited better corrosion properties and cell activities when exposed to rat skeletal muscle (L6) cells compared to pure Mg [11]. Furthermore, lamellar-structured composites of $\mathrm{Mg}-\mathrm{HA}$ were produced by spark plasma sintering and better fracture toughness was observed for $\mathrm{Mg}-8 \% \mathrm{HA}$ composites $\left(8.1 \mathrm{MPa} \mathrm{m}^{1 / 2}\right.$ ) compared to $\mathrm{Mg}-10 \% \mathrm{HA}\left(6.3 \mathrm{MPa} \mathrm{m}^{1 / 2}\right.$ ) and $\mathrm{Mg}-15 \%$ HA (5.1 $\mathrm{MPa} \mathrm{m}^{1 / 2}$ ) composites [13]. Recently, Saremi and Kavosi [30] produced Mg-based composites through powder metallurgy route by using HA reinforcement to study the HA size effect on the microstructure and mechanical properties. A relatively better distribution and higher mechanical properties were reported with nanoHA compared to microHA. The composite with 3 wt. $\%$ nanoHA showed higher hardness (80.8 Hv) compared to $\mathrm{Mg}-10 \mathrm{wt} \%$ microHA composite. The effect of nanoHA addition on improving the mechanical properties is similar to that of the earlier findings [11,13,31]. Table 1 summarizes the influence of HA on the material properties in developing $\mathrm{Mg}-\mathrm{HA}$ composites from the literature.

Recently, FSP has become a potential route to fabricate composites in the solid state. A few studies demonstrated that using FSP to develop Mg-based composites targeted for different applications [41]. In FSP, a specially designed non-consumable rotating tool containing pin is plunged into the workpiece and a traverse motion is given to refine the microstructure. Fine grains are produced in the processed regions due to dynamic recrystallization [42]. FSP can be adopted to produce surface composites. FSP helps to introduce secondary phase particles into the matrix without melting the substrate [41]. Therefore, issues associated with melting of the substrate can be completely eliminated [42]. Additionally, FSP results in fine grains which further improve the mechanical properties. Hence, FSP has been selected for the present work to develop Mg-based composites. Among many methods, groove filling was demonstrated as optimum to incorporate more amounts of secondary particles including HA into the workpiece [43]. In our earlier work, we demonstrated a cheap method to produce HA from fish bones (fHA) [44] which reduces the production cost (5-10 times lower) of HA powder compared to the commercial HA available in the market. Therefore, in the present study, naturally derived HA was selected to produce $\mathrm{Mg}-\mathrm{HA}$ composites for biomedical applications. Microstructural features, corrosion and mechanical properties of the composite were investigated and presented.

\section{Experimental}

Sheets of size $100 \times 50 \times 5 \mathrm{~mm}^{3}$ were cut from a pure $\mathrm{Mg}$ $(99.5 \%)$ billet (Exclusive Magnesium, Hyderabad, India). A groove of size $1 \mathrm{~mm}$ width and $2 \mathrm{~mm}$ depth was produced on the surface of the sheets. Fish bone derived hydroxyapatite (fHA) powder was used as the dispersing phase which was obtained by using fish bones from the Krishna river (India). The preparation methodology of fHA from fish bones was reported elsewhere [44]. FSP was carried out using a vertical milling machine (Bharat Fritz Werner Ltd., India). Figure 1a schematically illustrates developing surface composites by FSP [43]. Before processing, the sheets were placed on the work table and properly fixed by using special attachments. Then, the groove on the workpiece was filled with HA as shown in figure $1 \mathrm{~b}$. Initially, a pin-less tool having a shoulder diameter of $20 \mathrm{~mm}$ was used to close the groove by doing simple surfacing to eliminate the spillage of HA powder during FSP (as schematically shown in figure 1a). The FSP tool was made of H13 tool steel. The FSP tool has a shoulder diameter of $20 \mathrm{~mm}$ with a tapered pin of $5 \mathrm{~mm}$ diameter and a length of $3 \mathrm{~mm}$ with an end diameter of $2 \mathrm{~mm}$. Preliminary experiments were performed and process parameters were optimized. Then FSP was carried out by using the FSP tool to produce a composite as schematically shown in figure 1a with a $1400 \mathrm{rpm}$ tool rotational speed, $25 \mathrm{~mm} \mathrm{~min}^{-1}$ feed and $3.1 \mathrm{~mm}$ penetration depth. Figure 1c shows the photograph of the resulting composite after one FSP pass. The resulting composite after FSP was coded as Mg-fHA. In FSP, it is difficult to measure the exact amount of the secondary phase that is introduced into the surface. During the filling of fHA into the groove provided in the workpiece, it is assumed that $70 \%$ of the volume of the groove is filled by tapping the workpiece. Hence, it is assumed that the fHA powder has been filled in the groove with $70 \%$ tap density.

The fHA powders were characterized by scanning electron microscopy (SEM, Quanta 200, The Netherlands). Elemental composition was measured by energy dispersive spectroscopy (EDS) analysis. Furthermore, the powder was ultrasonically dispersed in ethanol and transmission electron microscopy (TEM, Tecnai $\mathrm{G}^{2}$ ) was carried out. Specimens were obtained from the FSPed zone to study the microstructure and properties. The samples were metallographically polished as per standard procedure and etched with a picric acid reagent. Optical microscopy (Leica, Germany) images were recorded in different regions. Microhardness (Omnitech, India) was measured on the base material and across the FSPed region on the composite after properly polishing up to 2000 grade emery 
Table 1. Brief survey on developing Mg-HA composites by different routes for biomedical applications.

\begin{tabular}{|c|c|c|c|c|}
\hline \multicolumn{2}{|c|}{ Composition } & \multirow[b]{2}{*}{ Processing route } & \multirow{2}{*}{$\begin{array}{l}\text { Effect of HA addition on } \\
\text { properties }\end{array}$} & \multirow[b]{2}{*}{ Authors } \\
\hline Matrix & Dispersing phase & & & \\
\hline AZ91D Mg alloy & 20 wt. $\%$ HA & $\begin{array}{l}\text { Powder } \\
\text { metallurgy and } \\
\text { extrusion }\end{array}$ & $\begin{array}{l}\text { Enhanced corrosion } \\
\text { resistance in artificial sea } \\
\text { water and cell solutions }\end{array}$ & Witte et al [32] \\
\hline AZ91 Mg alloy & $20 \%$ fluorapatite (FA) & $\begin{array}{l}\text { Blending- } \\
\text { pressing and } \\
\text { sintering }\end{array}$ & $\begin{array}{l}\text { Decreased corrosion rate and } \\
\text { increased deposition of } \\
\text { apatite in simulated body } \\
\text { fluids }\end{array}$ & Razavi et al [33] \\
\hline Pure Mg & 5,10 and $15 \% \mathrm{HA}$ & $\begin{array}{l}\text { Melting and } \\
\text { extrusion }\end{array}$ & $\begin{array}{l}\text { Decreased tensile strength } \\
\text { and increased compressive } \\
\text { strength with higher \% of } \\
\text { HA }\end{array}$ & Khanra et al [26] \\
\hline Pure Mg & 10,20 and $30 \% \mathrm{HA}$ & $\begin{array}{l}\text { Powder } \\
\text { metallurgy }\end{array}$ & $\begin{array}{l}\text { Decreased strength, ductility } \\
\text { and corrosion resistance }\end{array}$ & Gu et al [27] \\
\hline $\mathrm{Mg}-\mathrm{Zn}-\mathrm{Zr}$ alloy & NanoHA & $\begin{array}{l}\text { Melting and } \\
\text { extrusion }\end{array}$ & $\begin{array}{l}\text { Increased corrosion resistance } \\
\text { and in vitro biocompatibility }\end{array}$ & Ye et al [34] \\
\hline $\mathrm{Mg}-6 \% \mathrm{Zn}$ alloy & $5 \% \mathrm{HA}$ & $\begin{array}{l}\text { Powder } \\
\text { metallurgy }\end{array}$ & $\begin{array}{l}\text { Increased mechanical and } \\
\text { corrosion properties }\end{array}$ & Zhao et al [35] \\
\hline Pure $\mathrm{Mg}$ & $1 \% \mathrm{HA}$ & Sintering & $\begin{array}{l}\text { Increased compressive } \\
\text { strength }\end{array}$ & Khalil and Almajid [28] \\
\hline Pure Mg & 10 and $20 \% \mathrm{HA}$ & PEO & $\begin{array}{l}\text { Decreased corrosion } \\
\text { resistance }\end{array}$ & Viswanathan et al [29] \\
\hline $\mathrm{Mg}-3 \mathrm{Zn}-0.5 \mathrm{Zr}$ alloy & $0,0.5,1$ and 1.5 wt. $\%$ HA & $\begin{array}{l}\text { Melting and } \\
\text { extrusion }\end{array}$ & $\begin{array}{l}\text { Improved mechanical } \\
\text { properties and corrosion } \\
\text { resistance }\end{array}$ & Sun et al [36] \\
\hline AZ31 Mg alloy & HA (amount not mentioned) & FSP & $\begin{array}{l}\text { Improved surface energy, } \\
\text { biomineralization and } \\
\text { bioactivity }\end{array}$ & Ratna Sunil et al [11] \\
\hline Pure Mg & HA (amount not mentioned) & FSP & $\begin{array}{l}\text { Increased biomineralization } \\
\text { due to the presence of HA }\end{array}$ & Keerthi Soujanya et al [12] \\
\hline Pure Mg & 5,8 and $10 \% \mathrm{HA}$ & $\begin{array}{l}\text { Spark plasma } \\
\text { sintering }\end{array}$ & $\begin{array}{l}\text { Better fracture toughness and } \\
\text { corrosion resistance with } \\
8 \% \text { HA }\end{array}$ & Ratna Sunil et al [37] \\
\hline Pure $\mathrm{Mg}$ & $0,2,5$ and $10 \mathrm{wt} \% \mathrm{HA}$ & $\begin{array}{l}\text { Extrusion and } \\
\text { spark plasma } \\
\text { sintering }\end{array}$ & $\begin{array}{l}5 \text { wt.\% HA was found to be } \\
\text { optimum composition for } \\
\text { better mechanical properties }\end{array}$ & Kubásek et al [38] \\
\hline Pure $\mathrm{Mg}$ & Cow bones derived HA & $\begin{array}{l}\text { Powder } \\
\text { metallurgy }\end{array}$ & $\begin{array}{l}\text { Addition of HA ( } 5 \text { wt. } \% \text { ) } \\
\text { decreased the crystallite size } \\
\text { and increased the hardness }\end{array}$ & Manalu et al [39] \\
\hline AZ91 Mg alloy & Porous HA & Squeeze casting & $\begin{array}{l}\text { The composite exhibited } \\
\text { higher compressive strength } \\
\text { and experienced brittle } \\
\text { fracture }\end{array}$ & Chen et al [40] \\
\hline Pure $\mathrm{Mg}$ & Nano/micro HA & $\begin{array}{l}\text { Blending-cold } \\
\text { pressing-hot } \\
\text { pressing }\end{array}$ & $\begin{array}{l}\text { Addition of } 3 \% \text { nano-HA has } \\
\text { shown superior mechanical } \\
\text { properties compared with } \\
\text { microHA }\end{array}$ & Saremi and Kavosi [30] \\
\hline
\end{tabular}

sheets. During measurement of the hardness, a $100 \mathrm{~g}$ load was applied for a dwell time of $10 \mathrm{~s}$. For every $2 \mathrm{~mm}$ of distance across the samples, one measurement was obtained. The measurements were conducted in the stir zone and also at the base material.
The corrosion performance of the samples was assessed by using $3.5 \% \mathrm{NaCl}$ solution. Potentiodynamic polarization curves were obtained using an electrochemical work station. During testing, a graphite rod and a saturated calomel electrode (SCE) were used as counter electrode and reference 


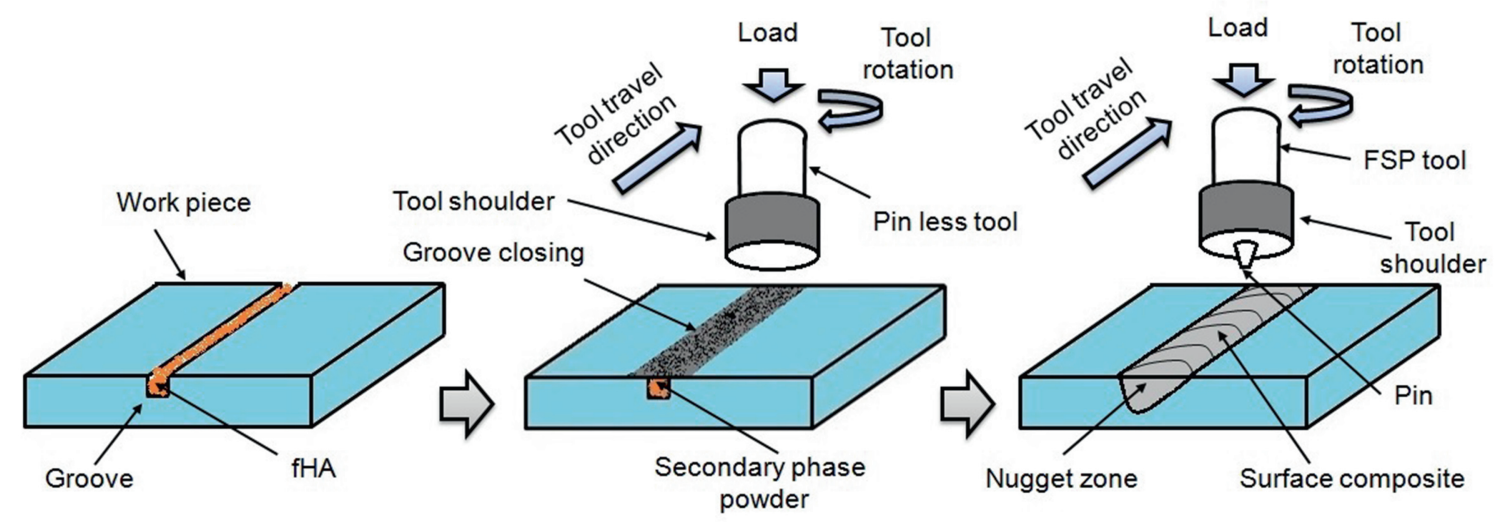

(a)

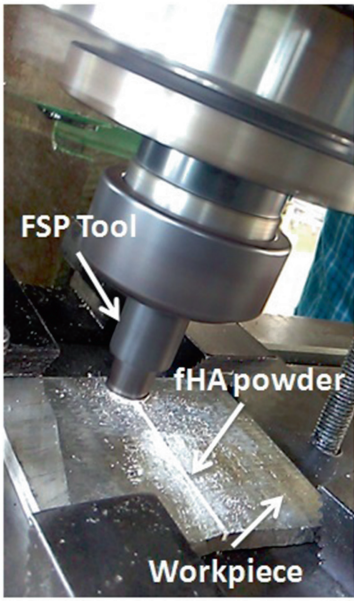

(b)

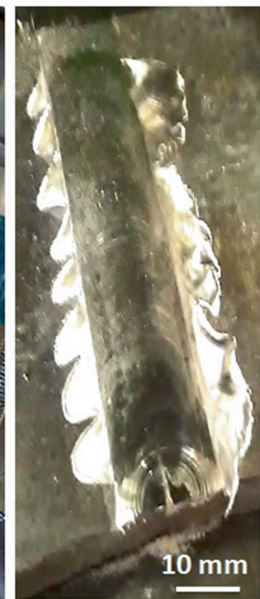

(c)

Figure 1. (a) Schematic representation of composite fabrication by FSP (source: Ratna Sunil [43]), (b) photograph showing composite fabrication by FSP and (c) processed region of the sample.

electrode, respectively. The workpiece, known as the working electrode was brought into the contact $\left(1 \mathrm{~cm}^{2}\right.$ area) with the electrolyte. An open circuit potential (OCP) was established for $30 \mathrm{~min}$ and then scanning was performed with a rate of $5 \mathrm{mV} \mathrm{s}^{-1}$. The obtained plots were analysed using Tafel exploration [45]. For tensile testing, the specimens as per the ASTM-E8 standards [46] were cut across the FSPed region. The tensile test was conducted at room temperature with a strain rate of $0.001 \mathrm{~s}^{-1}$ (Zwick-Roell, Germany). From the tensile data, stress-strain curves were developed and mechanical properties were obtained and compared among the samples. Figure 2 shows the flow chart of the present work.

\section{Results and discussion}

Producing HA through natural resources such as fish bones at reduced cost, enables biomedical engineers to develop several medical implants at lower cost where HA can play an important role. In the present study, produced fHA was successfully introduced into pure $\mathrm{Mg}$ within the solid state to develop composites. Figure 3 a shows a typical optical microscope image of pure $\mathrm{Mg}$ used in the present study. The grain size of the as-received $\mathrm{Mg}$ was measured as $\approx 2000 \mu \mathrm{m}$. The grain structure was observed as a cast structure i.e., a combination of elongated columnar grains and equiaxed grains. Figure $3 b$ shows the TEM bright field image of fHA used in the present work and the selective area electron diffraction (SAED) pattern of fHA. The average crystal size of fHA was measured as $<100 \mathrm{~nm}$. From the SAED pattern, the appearance of a ring-like pattern also confirms the nanoscale of the used fHA in the present work. The SEM image of fHA (figure 3c) shows the agglomerated fHA crystals and the corresponding EDS pattern confirms the presence of $\mathrm{Ca}, \mathrm{P}, \mathrm{O}$, $\mathrm{Mg}$ and $\mathrm{C}$. It is obvious that $\mathrm{Ca}, \mathrm{P}$ and $\mathrm{O}$ correspond to $\mathrm{HA}$. It is common to find the presence of other elements in HA produced from naturally derived sources [21-25], in addition 


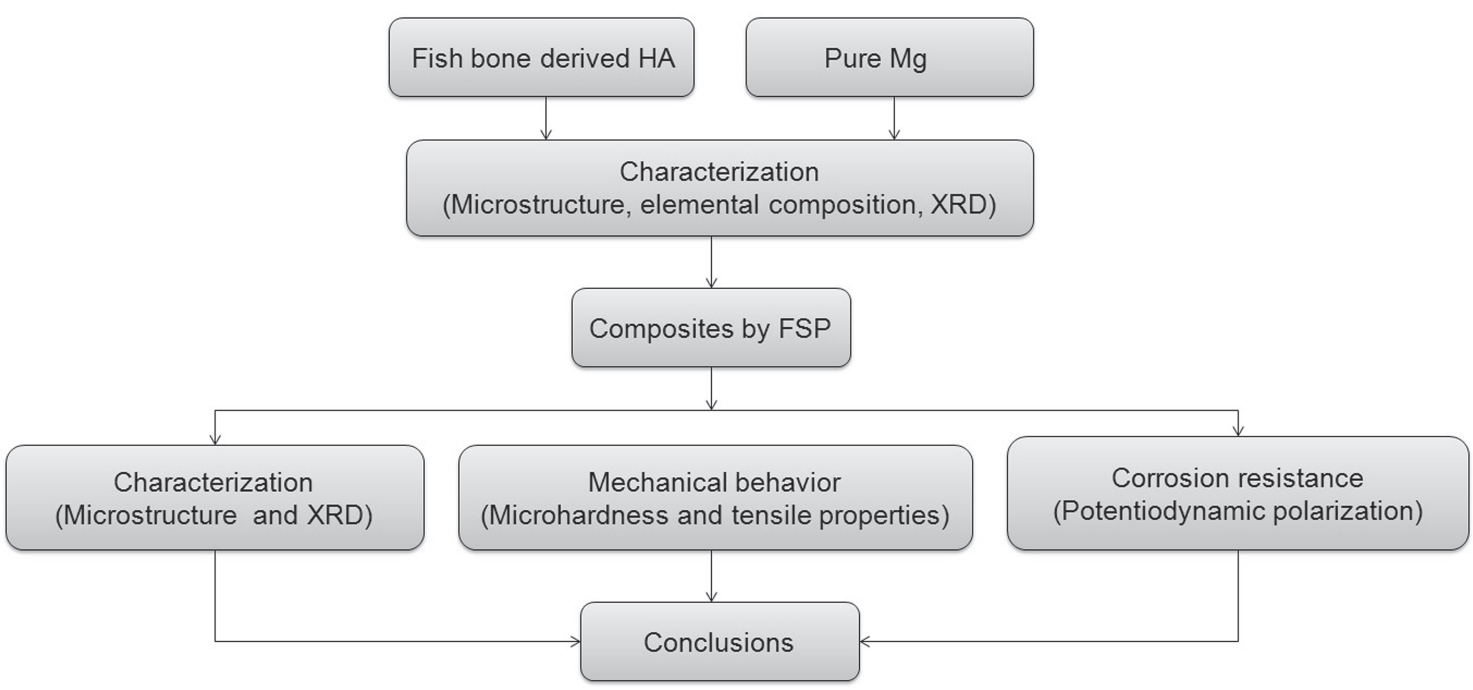

Figure 2. Flow chart showing sequence of different work elements in the present study.
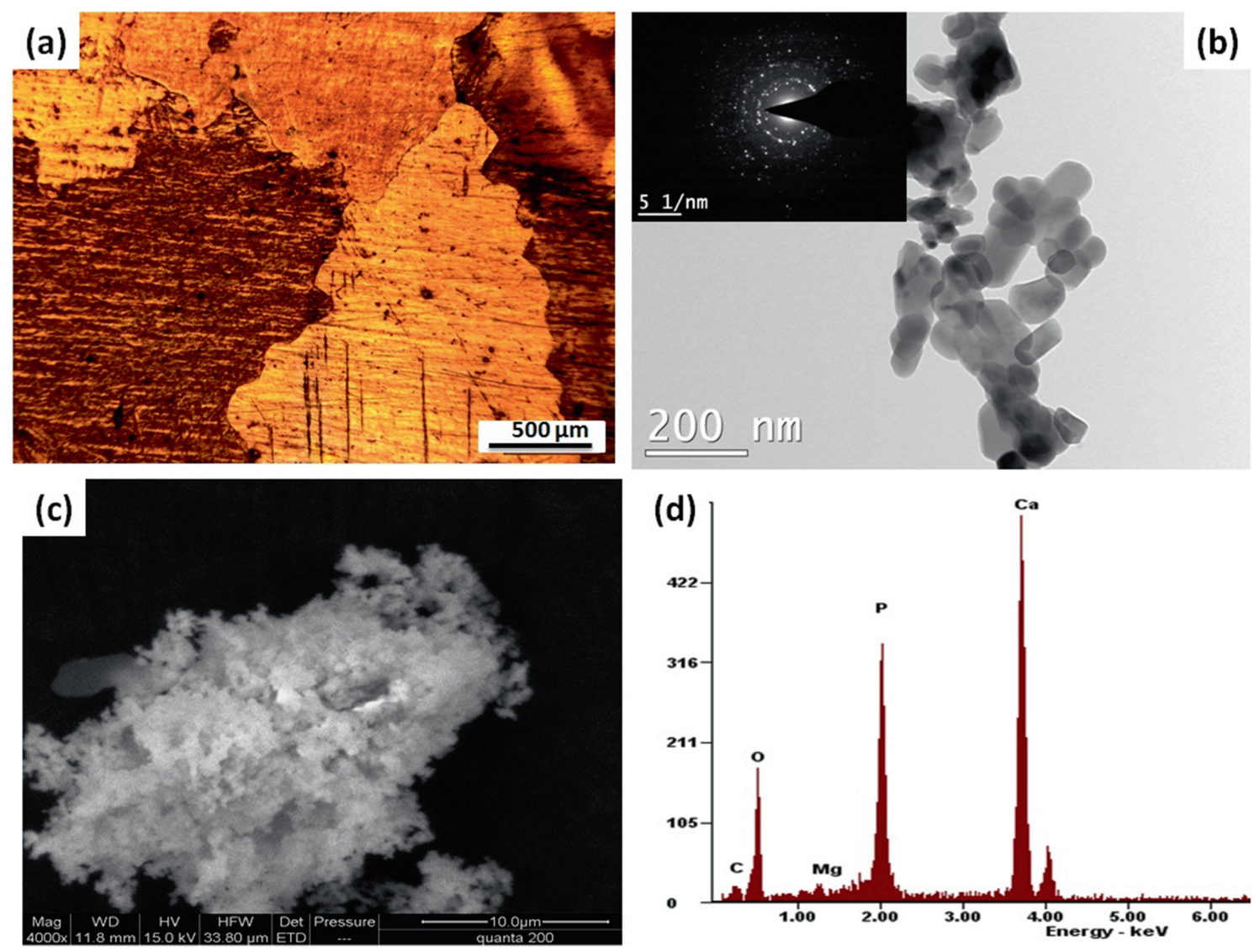

Figure 3. Microstructural observations of raw materials: (a) optical microscopy image showing grains and grain boundaries of the pure $\mathrm{Mg}$ sheet, (b) TEM bright field image of fHA powder used in the present work and corresponding selective area electron diffraction (SAED) pattern, (c) SEM image of agglomerated fHA and (d) corresponding EDS analysis showing the presence of $\mathrm{Ca}, \mathrm{P}, \mathrm{O}$ and $\mathrm{C}$ elements in $\mathrm{fHA}$.

to the presence of $\mathrm{Mg}$ in fHA. The presence of $\mathrm{C}$ is usually expected as the powder is pasted on the carbon tape, while conducting SEM studies.
Figure 4 shows the X-ray diffraction (XRD) plot of fHA heated up to $1000^{\circ} \mathrm{C}$. From the XRD pattern, no new peaks appeared even after heating up to $1000^{\circ} \mathrm{C}$ which is an 


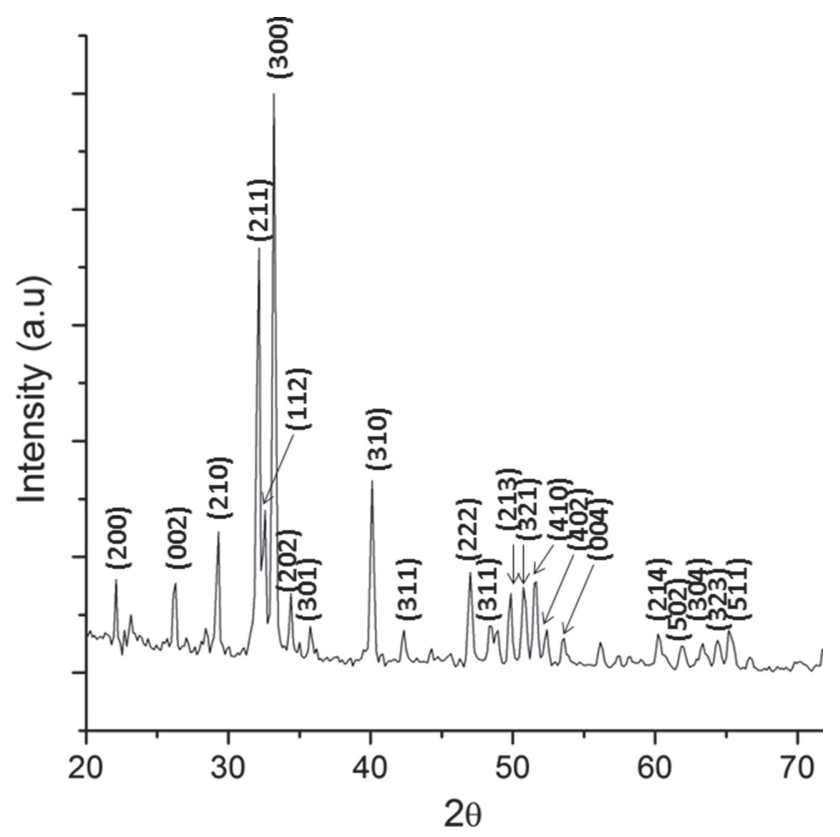

Figure 4. XRD pattern of fHA powder heated up to $1000^{\circ} \mathrm{C}$ confirming the prepared fHA is free from impurities and is also similar to the pure HA.

indication that the produced fHA is pure with a calcium (Ca) to phosphorous $(\mathrm{P})$ ratio close to 1.67. If $\mathrm{HA}$ is calcium deficient, i.e., the $\mathrm{Ca} / \mathrm{P}$ ratio is $<1.67$, new peaks corresponding to $\beta$-tri-calcium phosphate appear in the XRD pattern, if heated above $650^{\circ} \mathrm{C}$ [47-49]. The stable nature of fHA up to $1000^{\circ} \mathrm{C}$ also confirms that the heat produced during FSP does not affect the fHA phase stability. During FSP, the temperatures within the stir zone do not exceed $>0.8$ times that of the base material melting point. The pure $\mathrm{Mg}$ melting point is $650^{\circ} \mathrm{C}$ and it is observed from figure 4 that fHA used in the present work is stable up to $1000^{\circ} \mathrm{C}$. Therefore, it can be understood that fHA used as the dispersing phase in the present study does not show any phase transformations during FSP due to the produced heat in the stir zone.

Figure 5 shows a comparison of the XRD patterns of pure $\mathrm{Mg}$ and $\mathrm{Mg}$-fHA. It is a clear observation that the peaks corresponding to fHA are not identified from the Mg-fHA XRD plot due to the lower amount of introduced fHA into $\mathrm{Mg}$ which might be lower than the XRD detecting level. However, the Mg-fHA composite shows different intensities for all the peaks relatively compared with pure $\mathrm{Mg}$. It can be seen from the XRD patterns (figure 5) that the peak intensities of (002) and (004) were increased and the peak intensities of (100), (101), (102), (110), (103), (112) and (201) were decreased. This observation strongly suggests the introduced texture effect due to FSP. During FSP, the generated heat helps the material to plastically flow as per the FSP tool pin stirring direction and then the shoulder imposes the hydrostatic pressure upon the material beneath the shoulder [21]. Therefore, the material flow during FSP occurs due to the

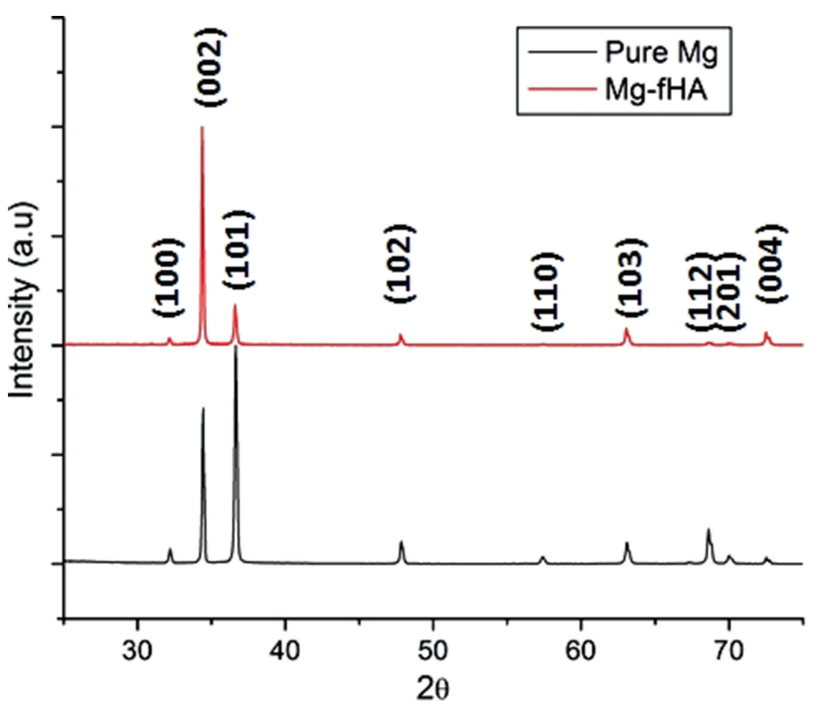

Figure 5. XRD pattern of pure $\mathrm{Mg}$ and $\mathrm{Mg}$-fHA composites shows the texture effect after FSP.

plastic deformation with the most possible slip plane (002) (as the crystal structure of $\mathrm{Mg}$ is hcp). The basal plane in hcp crystal metals is the highest atomic density plane. Several structural sensitive properties are certainly influenced by the change in the fraction of the grains with close-packed planes (002). Hence, this orientation change in the Mg-fHA composite compared with pure $\mathrm{Mg}$ is believed to be one of the important factors in altering the properties of the composite.

Figure 6 shows the microstructure of the composite at the cross section. From figure $6 a$, the affected region due to FSP can be clearly seen. The retreating side of the stir zone has a sharp thermomechanical affected zone (TMAZ) as indicated with an arrow compared with the advancing side. Additionally, the retreating side has more amounts of fHA accumulation compared to the advancing side. Figure $6 \mathrm{~b}$ shows the flow of the material and incorporated fHA. More agglomerated fHA can also be observed in the magnified image of the nugget zone as shown in figure 6c. Surprisingly, at the advancing side as shown in figure 6d, very little amount of fHA was noticed. Grain refinement was observed up to $10 \mu \mathrm{m}$ from the starting size of $2000 \mu \mathrm{m}$. The dynamic recrystallization causes the grain refinement during FSP [21]. From the observations, the thickness of the affected region was measured as $2.5 \mathrm{~mm}$. It is obvious that the thickness of the affected zone is with respect to the FSP tool pin length. In the present study, a $3 \mathrm{~mm}$ length tapered pin was used for processing. Hence, the affected thickness was limited to $2.5 \mathrm{~mm}$ thickness.

Figure 7 shows the microhardness measurements of $\mathrm{Mg}$ and $\mathrm{Mg}$-fHA composites. It can be seen from the results that the composite has higher hardness. The variations within the stir zone (composite) can be observed as higher. It is similar to the earlier reports that the composites produced by FSP exhibit variations in hardness within the nugget region [41,50,51]. 


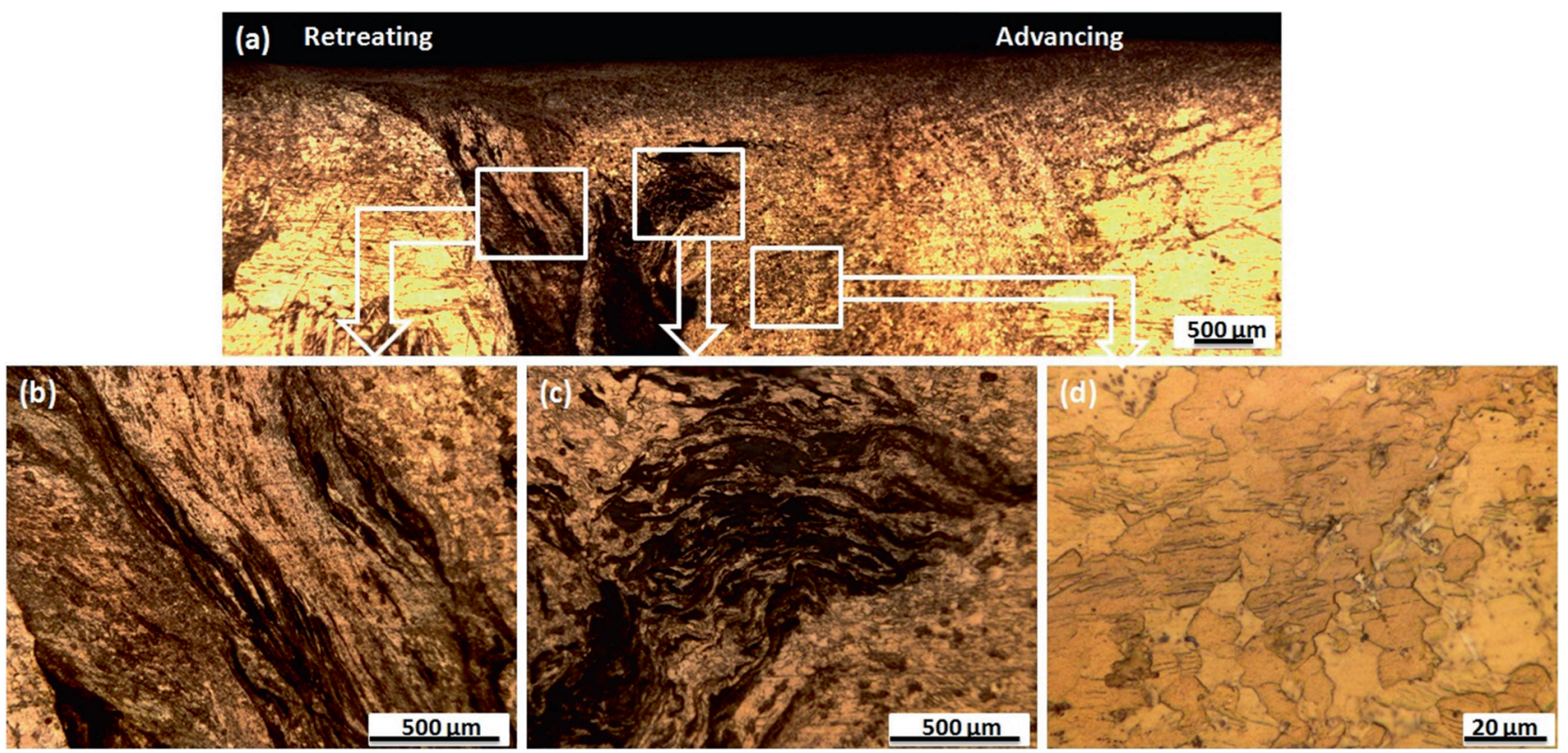

Figure 6. Optical microscopy images of the FSPed composite: (a) obtained at cross section, (b) corresponding magnified image showing the presence of the secondary phase, (c) agglomerated fHA in the stir zone and (d) magnified image showing fine grains after FSP at the surface of the stir zone.
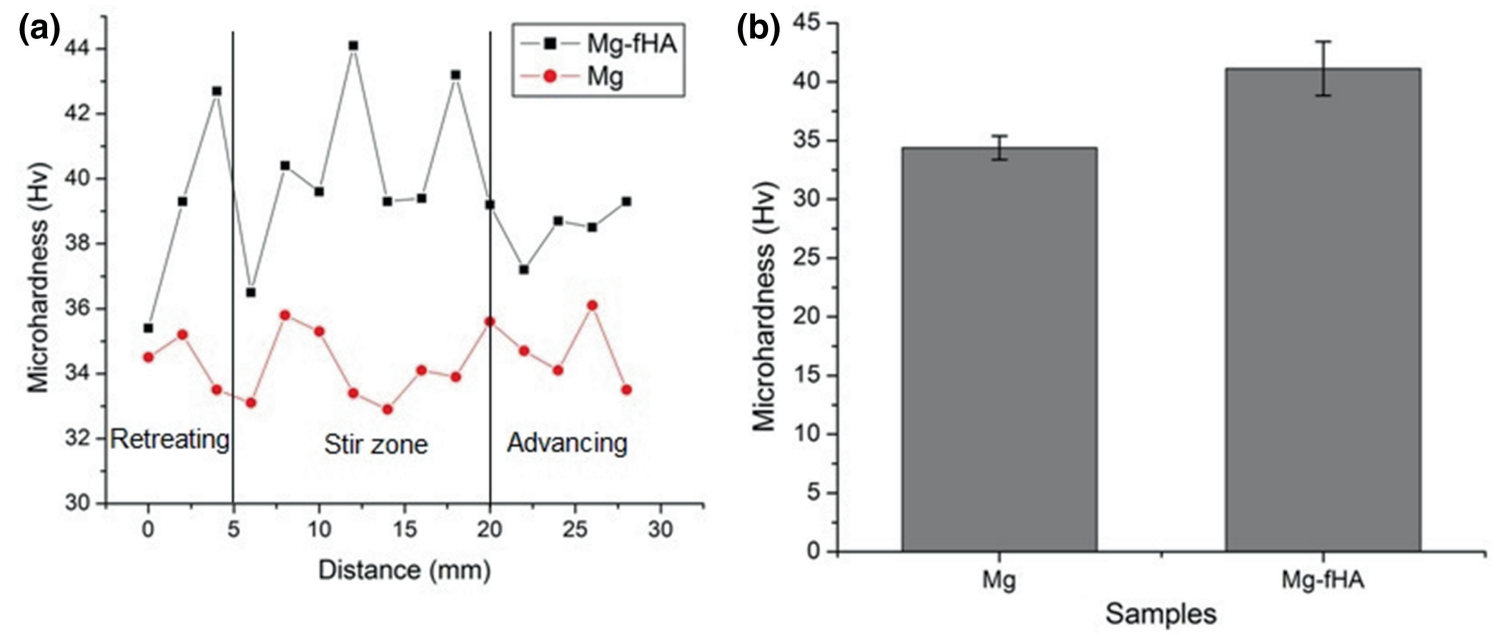

Figure 7. Microhardness measurements of pure $\mathrm{Mg}$ and $\mathrm{Mg}-\mathrm{fHA}$ : (a) hardness distribution across the sample and (b) average hardness.

It is also observed that the hardness has been increased adjacent to the stir zone in TMAZ and the heat affected zone (HAZ). The development of smaller grains and several twins has been clearly observed in the TMAZ and HAZ regions of FSPed pure Mg in our earlier study [52]. Therefore, the presence of these smaller grains and twins increased the hardness as observed in the current study in the advancing and retreating side of the Mg-fHA composite as shown in figure 7a. Two prominent reasons behind the increased hardness in the stir zone of the $\mathrm{Mg}-\mathrm{fHA}$ composite are: (i) smaller grain size and (ii) the presence of fHA. Smaller grains increase the ability of the material to resist the plastic deformation which in fact reflected as increased hardness in the present study. Additionally, the presence of nanofHA also introduces dispersion strengthening to the composite. Therefore, the Mg-fHA composite exhibited increased hardness $(41.1 \pm 2.3)$ compared with pure $\mathrm{Mg}(34.4 \pm 1.1)$ (figure $7 \mathrm{~b}$ ).

Figure 8a shows the photographs of the tensile samples before and after testing. The engineering stress-strain curves of the specimens are shown in figure $8 \mathrm{~b}$ and the mechanical properties are listed in table 2 . Surprisingly, the composite failed at lower loads compared with pure $\mathrm{Mg}$. 
(a)
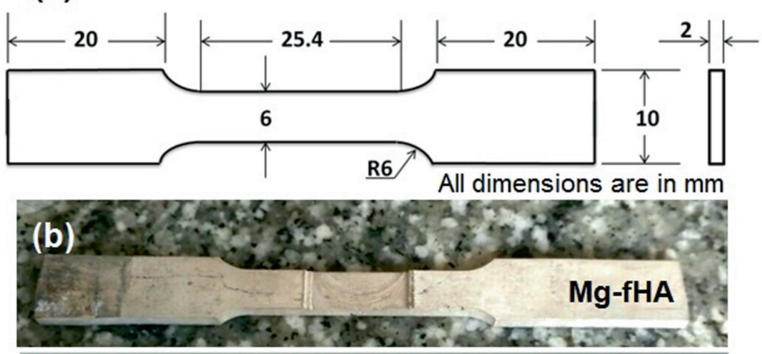

(c)

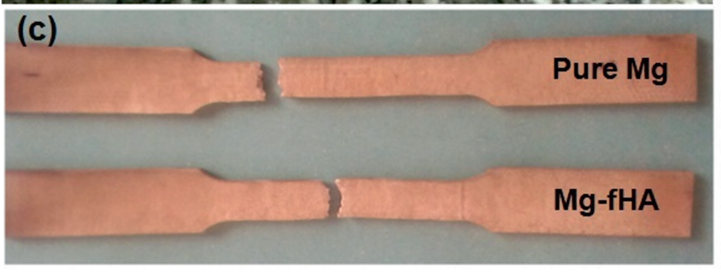

(d)

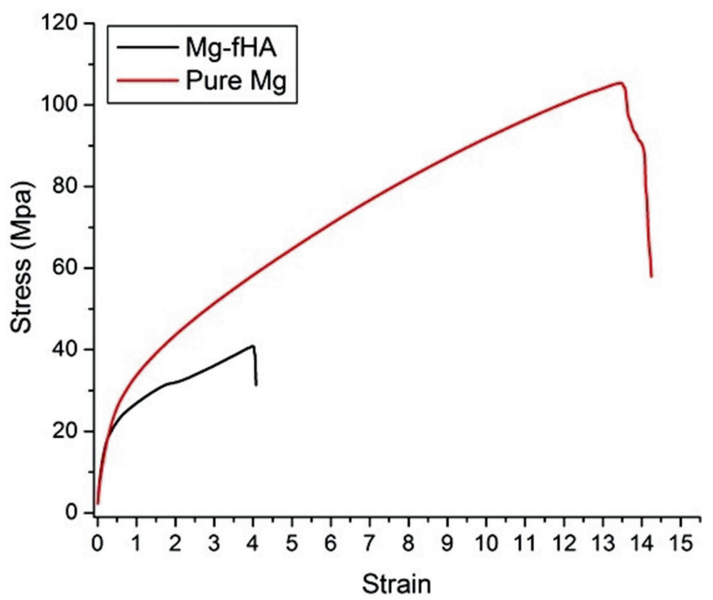

Figure 8. (a) Tensile specimen dimensions as per ASTM sub-size standards, (b) photograph of the Mg-fHA specimen before polishing, (c) photograph of the specimens after the tensile test and (d) engineering stress-strain curves of the samples.

Table 2. Mechanical properties of the samples obtained from tensile tests.

\begin{tabular}{lccc}
\hline Specimen & UTS (MPa) & $\begin{array}{c}\text { Yield strength } \\
(\mathrm{MPa})\end{array}$ & \% of elongation \\
\hline Pure Mg & 105.2 & 57.9 & 14.2 \\
Mg-fHA & 40.3 & 31.3 & 4.02 \\
\hline
\end{tabular}

The reasons behind the decreased mechanical properties could be agglomerations of fHA nanoparticles as observed in the microstructural studies which apparently decrease the yield strength, UTS and \% elongation. The presence of fHA powder in $\mathrm{Mg}$ made the composite more brittle as observed from the decreased $\%$ elongation for the composite $(4.02 \%)$ compared to pure $\mathrm{Mg}(14.2 \%)$. The \% elongation of the composite is observed as close to natural bone (4\%), but the tensile strength is lower than the required value to match with the natural bone. However, with these mechanical properties, the composite may not be suitable for load-bearing orthopaedic implant applications, but best suited for degradable tissue scaffold applications. The potentiodynamic polarization curves obtained from the corrosion tests of samples are shown in figure 9 and the corresponding electrochemical parameters $\left(i_{\text {corr }}\right.$ and $\left.E_{\text {corr }}\right)$ are provided in table 3 .

The corrosion potential ( $E_{\text {corr }}$ ) for $\mathrm{Mg}-\mathrm{fHA}$ was measured as lower compared to pure $\mathrm{Mg}$. The $i_{\text {corr }}$ for the composite was measured as marginally lower compared to pure $\mathrm{Mg}$. These observations suggest the noble behaviour of the $\mathrm{Mg}-$ fHA composite compared to pure $\mathrm{Mg}$. The important factors which affect the corrosion behaviour of $\mathrm{Mg}-\mathrm{fHA}$ composite are: (i) smaller grain size, (ii) preferred orientation and (iii) incorporated fHA particles. The grain boundaries in $\mathrm{Mg}$

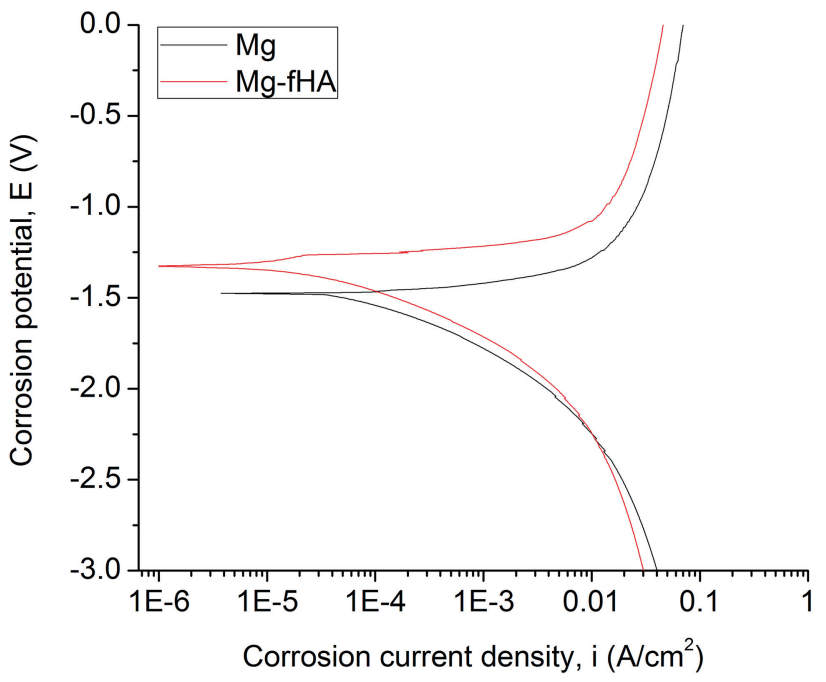

Figure 9. Potentiodynamic polarization curves of $\mathrm{Mg}$ and $\mathrm{Mg}-$ fHA composites obtained from the corrosion tests.

Table 3. Electrochemical parameters of $\mathrm{Mg}$ and $\mathrm{Mg}-\mathrm{fHA}$ obtained from Tafel exploration.

\begin{tabular}{lcc}
\hline Sample & $\begin{array}{c}\text { Corrosion potential } \\
\left(E_{\text {corr }}\right)(\mathrm{mV})\end{array}$ & $\begin{array}{c}\text { Corrosion current } \\
\text { density } i_{\text {corr }}\left(\mathrm{A} \mathrm{cm}^{-2}\right)\end{array}$ \\
\hline Pure Mg & -1453 & $33.44 \times 10^{3}$ \\
Mg-fHA & 1305 & $24.53 \times 10^{3}$ \\
\hline
\end{tabular}

behave as a cathode and grain inner regions behave as anode. Therefore, the reduced grain size after FSP, certainly introduces a cathodic branch shift as observed for the $\mathrm{Mg}-\mathrm{fHA}$ composite [53]. As observed from the XRD studies (figure 5), 
preferred orientations of (002) basal planes in the grains of the $\mathrm{Mg}-\mathrm{fHA}$ composite offer lower dissolution as these planes are high density planes in the hcp crystal structure. Additionally, the presence of fHA powder in the Mg matrix affects the galvanic intensities. Overall, the cumulative effect of the grain size, texture effect and addition of the secondary phase (fHA) introduced a slight corrosion resistance to the composite.

The mechanical characteristics are not of prime concern behind developing Mg-based composites for scaffold applications as long as the composite exhibits mechanical properties close to the natural bone. In the context of bioactivity and degradation of $\mathrm{Mg}$ in a physiological environment, surface modification is crucial. Altering the surface microstructure and chemical composition with bioactive phases, such as HA, favours better tissue interactions. By incorporating fHA up to a certain thickness promisingly enhances the bio-performance of the composite and further influences the electrochemical events at the surface. The significant point that should be noticed in the present work is that the fHA powder was introduced into $\mathrm{Mg}$ without deteriorating the corrosion performance which is an advantage as fHA enhances the bioactivity of the composite that promotes higher mineral deposition and further decreases the degradation rate and increases the tissue response at the implant surface [11].

Hence, it can be understood that using fish bone derived HA as a dispersing phase to enhance the bioactivity without altering the corrosion resistance of the composites is the best strategy to develop degradable scaffolds to use as a promising material for bone filling and repair of fractured bones in the medical industry. The advantage of the decreased grain size and the presence of fHA to promote higher bioactivity can also be coupled if $\mathrm{Mg}$-fHA composites are fabricated by FSP. In addition, the cost of fHA is lower when compared with commercially available grades. Therefore, the overall cost to develop the implant can also be reduced. To improve the mechanical properties of the $\mathrm{Mg}$-fHA composite close to that of a natural bone, the amount and dispersion of fHA need to be optimized with further experiments. Achieving a uniform distribution of the dispersing phase in FSP is a challenge. To achieve uniformity in the distribution of the secondary phase, more number of FSP passes may be required. Additionally, by increasing the number of FSP passes, the microstructure can also be further refined. However, finding an optimum number of FSP passes is crucial to avoid grain growth issues [41,42]. A careful study to tailor the corrosion behavior when altering the amount and distribution of fHA is also recommended to ensure that the presence of more fHA does not deteriorate the corrosion rate of $\mathrm{Mg}$.

\section{Conclusions}

In the present work, fHA powder produced from fish bones was used as a dispersing phase to develop $\mathrm{Mg}$ based composites for degradable scaffolds in biomedical applications. Grain refinement was achieved from $\approx 2000$ to $10 \mu \mathrm{m}$ in the stir zone. The effective thickness of the composite at the surface was measured as $2.5 \mathrm{~mm}$. Increased hardness was measured in the $\mathrm{Mg}-\mathrm{fHA}$ composite due to the smaller grain size and the addition of fHA powder compared to pure $\mathrm{Mg}$. Interestingly, tensile properties were deteriorated in the composites compared to pure $\mathrm{Mg}$. The combined effect of smaller grain size, texture and the presence of fHA in $\mathrm{Mg}$ led to a marginal increase of the corrosion resistance in the $\mathrm{Mg}$-fHA composite compared to pure Mg. Hence, it can be concluded that a low-cost Mg-fHA composite can be easily produced by FSP with better corrosion performance; however, there is a need for a detailed study to optimize the composition to achieve the composite mechanical behaviour close to the human bone.

\section{Acknowledgements}

Financial support for this research work was obtained from research project: IIIT/NUZ/ME/Project/03/2017, RGUKT Nuzvid, Andhra Pradesh, India.

\section{References}

[1] Frank W, Norbert H, Carla V, Smadar C, Kainer K U, Willumeit R et al 2008 Curr. Opin. Solid St. Mater. Sci. 1263

[2] Barbara A S, Elizabeth S and Sanna V 2008 Interface 1745

[3] Sigrid K, Brunner J G, Ben F and Sannakaisa V 2011 J. Biomed. Mater. Res. Part B: Appl. Biomater. 96B 84

[4] Zeng R and Dietzel W 2008 Adv. Eng. Mater. 10 B3

[5] Witte F, Kaese V, Haferkamp H, Switzerc E A, MeyerLindenberg, Wirth C J et al 2005 Biomaterials 263557

[6] Hornberger H, Virtanen S and Boccaccini A R 2012 Acta Biomater. 82442

[7] Shaylin S and George J D 2012 Acta Biomater. 820

[8] Wang H, Estrin Y and Zúberová Z 2008 Mater. Lett. 622476

[9] Chen X B, Birbilis N and Abbott T B 2011 Corrosion 67 035005-1

[10] Ahmad Z and Kwangmin L 2015 J. Alloys Compd. 629274

[11] Ratna Sunil B, Sampath Kumar T S, Uday C, Nandakumar V and Mukesh D 2014 Mater. Sci. Eng. C 39315

[12] Keerthi Soujanya G, Hanas T, Yogeshwar Chakrapani V, Ratna Sunil B and Sampath Kumar T S 2014 Procedia Mater. Sci. 5 817

[13] Ratna Sunil B, Ganapathy C, Sampath Kumar T S and Uday C 2014 J. Mech. Behav. Bio. Mater. 40178

[14] Santos M H, de Oliveira M, de Freitas Souza P, Mansur H S and Vasconcelos W L 2004 Mater. Res. 7625

[15] Rameshbabu N, Prasad Rao K and Sampath Kumar T S 2005 J. Mater. Sci. 406319

[16] Kojima Y, Kitazawa K and Nishimiya N 2012 J. Phys. Conf. Ser. 339012001

[17] Masuda Y, Matubara K and Sakka S 1999 J. Ceram. Soc. Jpn. 981266

[18] Shikhanzadeh M 1998 J. Mater. Sci.: Mater. Med. 967

[19] Suchanek W L and Riman R E 2006 Adv. Sci. Technol. 45184

[20] Jung S C and Yun C K 2008 J. Alloys Compd. 464282 
[21] Sivakumar M, Sampath Kumar T S, Shantha K L and Prasad Rao K 1996 Biomaterials 171709

[22] Krishna D S R, Siddharthan A, Seshadri S K and Sampath Kumar T S 2007 J. Mater. Sci.: Mater. Med. 181735

[23] Masakuni O and Suguru S 2002 J. Am. Ceram. Soc. 851315

[24] Boutinguiza M, Pou J, Comesaña R, Lusquiños F, de Carlos A and León B 2012 Mater. Sci. Eng. C 32478

[25] Yi-Cheng H, Pei-Chi H and Huey-Jine C 2011 Ceram. Int. 37 1825

[26] Khanra A K, Jung H C, Yu S H, Hong K S and Shin K S 2010 Bull. Mater. Sci. 3343

[27] Gu X, Zhou W, Zheng Y, Dong L, Xi Y and Chai D 2010 Mater. Sci. Eng. C $\mathbf{3 0} 827$

[28] Khalil K A and Almajid A 2012 Mater. Des. 3658

[29] Viswanathan R, Rameshbabu N, Kennedy S, Sreekanth D, Venkateswarlu K, Sandhya Rani M et al 2013 Mater. Sci. Forum 765827

[30] Saremi M and Kavosi N 2017 AIP Conf. Proc. 1896200011

[31] Pushan G, Zeqin C, Lijing Y, Linxin C, Wenxian W and Bingshe X 2016 Adv. Eng. Mater. 191600294

[32] Witte F, Feyerabend F, Maier P, Fischer J, Stormer M, Blawert C et al 2007 Biomaterials 282163

[33] Razavi M, Fathi M H and Meratian M 2010 Mater. Charact. 10 1363

[34] Ye X, Minfang C, Meng Y, Jun W and Debao L 2010 J. Mater. Sci.: Mater. Med. 211321

[35] Zhao J, Zhiming Y, Kun Y and Liangjian C 2011 Adv. Mater. Res. 239-242 1287

[36] Sun J, Chen M, Cao G, Bi Y, Liu D and Wei J 2013 J. Compos. Mater. 48825

[37] Ratna Sunil B, Ganapathy C, Sampath Kumar T S and Uday C 2014 J. Mech. Behav. Biomed. Mater. 40178
[38] Kubásek J, Dalibor V, Jaroslav M and Drahomír D 2015 Sci. Eng. Compos. Mater. 24297

[39] Manalu J L, Bambang S and Decky J I 2016 Asian J. Appl. Sci. Eng. 4810

[40] Chen B, Yin K-Y, Lu T-F, Sun B-Y, Qing D, Zheng J-X et al 2016 J. Mater. Sci. Technol. 32858

[41] Ratna Sunil B, Pradeep Kumar Reddy G, Hemendra P and Ravikumar D 2016 J. Magnes. Alloys 452

[42] Mishra R S and Ma Z Y 2005 Mater. Sci. Eng. R 501

[43] Ratna Sunil B 2016 Int. J. Mech. Mater. Eng. 1112

[44] Ratna Sunil B and Jagannatham M 2016 Mater. Lett. 185 411

[45] Mansfeld F 1976 in Fontana M G and Staettle R W (eds) Advances in corrosion science and engineering (New York: Plenum Press) p 163

[46] ASTM Standard E8/E8M-11 2009 Standard test methods for tension testing of metallic materials (West Conshohocken, PA, USA: ASTM International) https://doi.org/10. 1520/E0008_E0008M-11

[47] Siddharthan A, Seshadri S K and Sampath Kumar T S 2004 J. Mater. Sci.: Mater. Med. 151279

[48] Siddharthan A, Sampath Kumar T S and Seshadri S K 2009 Biomed. Mater. 4045010

[49] Siddharthan A, Seshadri S K and Sampath Kumar T S 2005 Trends Biomater. Artif. Organs $\mathbf{1 8} 110$

[50] Asadi P, Besharati Givi M K, Abrinia K, Taherishargh M and Salekrostam R 2011 JMEP 201554

[51] Zhang Z and Chen D L 2008 Mater. Sci. Eng. A 483-484 148

[52] Ratna Sunil B, Sampath Kumar T S and Uday C 2012 Mater. Sci. Forum 720264

[53] Miyamoto H, Harada K, Mimaki T, Vinogradov A and Hashimoto S 2008 Corros. Sci. 501215 